\title{
NÉHÁNY GONDOLAT A SZEMÉLYI JÖVEDELEMADÓZÁS ELSŐ HARMINC ÉVÉRŐL
}

\section{THE FIRST 30 YEARS-THINGKING OVER THE PERSONAL INCOME TAXATION IN HUNGARY}

\author{
Dr Lakatos Mária PhD* \\ Pénzügy és Számvitel Tanszék, Gazdaságtudományi Kar, Neumann János Egyetem, Magyarország \\ https://doi.org/10.47833/2020.1.ECO.003
}

\section{Kulcsszavak:}

gazdaságpolitika

reform

adózás

szociális elosztóendszer

személyi jövedelemadózás

\section{Keywords:}

economic policy

reform

taxation

social system

personal income tax

\section{Cikktörténet:}

Beérkezett 2019. december 2.

Átdolgozva 2019. december 17.

Elfogadva 2019. december 22.

\begin{abstract}
Összefoglalás
Tanulmányomban a magyar személyi adózási rendszer és az ehhez kapcsolódó gazdaságpolitikai változások alapvető fordulatait mutatom be az 1988 óta telt 30 évben. A történeti visszatekintés pedig lehetővé teszi, hogy felmérjük az egyes adóváltozásokra adott adófizetői válaszokat is. Az adórendszer bevezetése óta eltelt időszak változásai megmutatták az állami és az adófizetői magtartások közötti kapcsolatot is. Csak egy konszenzuson alapuló adópolitika lehet elfogadható mindkét fél számára, de az összefüggések egyelöre a megfigyelésen alapulnak és eröteljesen nemzeti karakterisztikával rendelkeznek.
\end{abstract}

Abstract
The changes of the Hungarian personal tax system and the
effects taken in the Hungarian economic policy sometimes
deriving from fundamental turns will be covered in my study
overlooking the period of the last 30 years beginning with 1988
in order to attempt to describe the current tax system. Such study
also gives a chance to analyze the behaviour of Hungarian tax
payers, their answers given to an amendment. The changes in
the tax system in the recent decades have, however, proved
some basic correlations between the acts of the state as well as
the individuals producing the income. That a consensual tax
policy can be considered acceptable for both parties, but there
have only been general correlations based exclusively on the
practical experience regarding the tax standard required for the
above mentioned consensus. These correlations are not be
generalized due to national characteristics..

\section{Bevezetés}

Már az 1980-as évek végén látható volt, hogy a szocialista közösség adta növekedési lehetőségek kimerültek, a Szovjetunió a peresztrojka ideje alatt meggyengült, nemcsak katonai, hanem gazdasági értelemben is. A felzárkózáshoz és egyáltalán a kétféle típusú gazdasági berendezkedés közelítéséhez, a gazdasági nyitáshoz átlátható belső árrendszerre,

\footnotetext{
* Kapcsolattartó szerző. Tel.: +36209540489

E-mail cím: lakatos.maria@gtk-uni.neumann.hu
} 
mérhetö, közvetett eszközökkel befolyásolható jövedelempolitikára, egységes és mindenképpen az EU-ban használatos hozzáadott-érték típusú forgalmi adózásra volt szükség. Elavultnak számított az adókból befolyt jövedelem szerkezete, elsősorban a vállalati szektor viselte az adók 63,2 százalékát. Ezen túlmenően az adóigazgatási eljárás teljes reformjára is elérkezett az idő. A szükséges politikai döntések után megszületett az adóreform, amelynek célja egy egységes, törvényileg szabályozott és normatív adórendszer kialakítása volt; olyan, társadalmilag igazságosabb közteherviselés megvalósítása, amelyik a jövedelmeket a keletkezésük helyén teszi láthatóvá, és ott is adóztatja azt. Cserébe viszont nagyobb beleszólást ígért a közpénzek újraelosztásában. A magyar, adózással foglalkozó szakirodalom általában az 1988-as reform hátterét, az alkalmazott szociálpolitikai megfontolásokhoz kötődő kedvezmények ellentmondásos hatását dolgozta fel, nagyrészt a kilencvenes évek közepéig, általában egy-egy adónemhez kapcsolódóan. Hiányos az elmúlt 30 év változásainak elemzése, általában csak az adóbevételek nagyságának alakulása, a költségvetés aktuális helyzetének elemzése, illetve az adókedvezmények hatásainak elemzése kapott hangsúlyt. A vonatkozó szakirodalom pedig még nem tárta fel, a módosítások milyen módon alakították át fokozatosan az elvonások célját és ennek következtében milyen adórendszer alakult ki 2006 végéig Magyarországon. Majd pedig miként módosultak a korábbi elképzelések 2010. után.

\section{Tárgyalás}

Az 1988 előtti szabályozás nagymértékben eltérően kezelte a különböző forrásokból és jogcímeken szerzett lakossági jövedelmeket, ebböl következően nem biztosíthatta a jövedelem nagyságával arányos közteherviselést sem. Az előzőeken túlmenően a lakosságot terhelő adók aránya a vállalati adóteherrel szemben aránytalanul alacsony volt, ez pedig eleve szükségessé tette, hogy a vállalati bérarányos adókat egy egységes jövedelemadóval váltsák fel.

1.Táblázat. Az 1988-as adótábla

\begin{tabular}{|l|l|}
\hline Adókulcsok & $0-60 \%$ \\
\hline Adótábla & 11 sáv \\
\hline Adómentes határ & évi 48.000 forint \\
\hline Kedvezmény & $\begin{array}{l}\text { alkalmazotti kedvezmény, } \\
\text { gyermekkedvezmény, } \\
\text { a munkahelyi étkezési hozzájárulás } \\
\text { adómentessége. } \\
\text { szellemi munka adókedvezménye }\end{array}$ \\
\hline Ingó-ingatlan & \begin{tabular}{l} 
összevonás alá eső jövedelem \\
\hline Külön adózó jövedelem adókulcsa
\end{tabular} \\
\hline Munkaadói járulék & csökkentette az adó alapját \\
\hline Befektetések & Egykulcsos 20 százalékos adók \\
\hline
\end{tabular}

Forrás: NAV archív 
A személyi jövedelemadó rendszere tulajdonképpen egybeolvasztotta a korábbi, különböző jogcímeken megkülönböztetett jövedelemkategóriákat, valamint kiterjesztette az adó hatókörét a lakosság pénzintézeti megtakarításainak korábban adómentes kamatára is, illetve az akkori értékpapírpiacon forgó kötvények kamatára is; de a személyi jövedelemadó bevezetése előtti időszakban mutatott megosztottságát megőrizte az 1988-as reform után is. Az 1988-tól induló személyi jövedelemadó a következő sajátosságokkal rendelkezett. [1]

Két alapvető kategóriába sorolta a jövedelmeket: az első, összevonás alá eső jövedelmek kategóriájába tartoztak a munkaviszonyból, mezőgazdasági szövetkezeti tagviszonyból, az ehhez kapcsolódó költségtérítésekből származó jövedelmek. Ugyancsak összevonás alá került az önálló tevékenységböl származó jövedelem, a nyugdíj adót nem viselő járandóságként „csak” megemelte a mellékkereset adóját, hiszen felsőbb sávba sorolta azt. A másik csoportba kerültek a külön adózó jövedelmek, kamat, osztalék stb.

A jövedelemforrások túlnyomó többségére összevonási kötelezettséget rendelt el, amelyre progresszív adótábla szerint kellett megállapítani az adókötelezettséget. A külön adózó jövedelmek azonban nem a 11 sávos progresszív adótábla alá tartoztak, hanem lineáris adót - forrásadót fizettek, pl. a kamat-, osztalékjövedelmek.

A személyi jövedelemadó rendszer elvileg az egyéni és társas vállalkozás üzleti nyeresége kivételével minden lakossági jövedelemre kiterjedő hatállyal működött. A vállalkozó magánszemélyekre egy sajátos „kétcsatornás adózási rendszer vonatkozott. Ennek lényege abban állt, hogy az egyéni vállalkozó és a társas vállalkozó üzleti nyeresége után 25 százalékos vállalkozói adót fizetett, míg a személyes célú nyereség-felhasználás összege a személyi jövedelemadó alá esett. Mint látható, már ekkor a lakosság vált a terhek fö hordozójává. [2]

2. Táblázat. Az államháztartás bevételeinek alakulása föbb források szerint (százalékban)3

\begin{tabular}{|l|l|l|l|l|l|l|l|}
\hline Év & 1987 & 1988 & 1989 & 1990 & 1991 & 1992 & 1993 \\
\hline $\begin{array}{l}\text { Gazdálkodó } \\
\text { szervezetek }\end{array}$ & 63,2 & 55,5 & 48,2 & 40,6 & 30,9 & 26,3 & 22,9 \\
\hline Lakosság1 & 25,0 & 32,2 & 34,8 & 36,9 & 38,9 & 39,3 & 38,8 \\
\hline Egyéb2 & 11,8 & 13,3 & 17,0 & 30,2 & 32,3 & 34,4 & 38,3 \\
\hline Összesen: & 100 & 100 & 100 & 100 & 100 & 100 & 100 \\
\hline
\end{tabular}

1 Személyi jövedelemadó, forgalmi adó, fogyasztási adó, egyéb lakossági befizetések

2 Átvett pénzeszközök, költségvetési szervezetek befizetései, adósságszolgálattal kapcsolatos bevételek

Forrás: Pénzügyminisztérium

A lakosság közvetlen adóterhei az 1988-as 9 százalékról 17 százalékra növekedtek az adóköteles jövedelmek százalékában, míg a jövedelmek átlagos adóterhe 5-15 százalék között mozgott. A lakossági közvetett adóterheket ebben az időszakban nem becsülték, arra való hivatkozással, hogy végső fogyasztónak számítanak az áfa körbe be nem jelentkezett kisvállalkozások, egyéni vállalkozók is, de hozzávetölegesen a háromkulcsos áfa átlagosan 10 százalékkal növelte a lakossági adóterheket.[3]

A költségvetés egyetlen év alatt új, korábban elképzelhetetlen mértékü bevételi forrásra tett szert, még akkor is, ha a bérbruttósítás (a vállalatok kiegészítették a béreket, hogy ne érje 
hátrány a munkavállalókat) bizonyos részét a költségvetés megtérítette a vállalatoknak. Mint az első hat év, valamint a bevezetés évét megelöző esztendő bevételeit tükröző statisztikák mutatják, a bevételek legnagyobb arányú növekedése a személyi jövedelemadót jellemezte, (még nettó jelenértéken is), miközben az általános forgalmi adó az inflációtól elmaradó ütemben emelkedett, a társasági adóból befolyt összeg pedig mérséklődött.

Költségvetési szinten teljesültek az elsődleges célok. Az adatokból a következő általános jellegü következtetések vonhatók le:

- a gazdálkodó szervezetek mind nominális értékben, mind az államháztartás bevételeihez viszonyított arányában csökkenő összeget fizettek be (egyedül a vám- és importbefizetéseknél beszélhetünk növekedésröl);

- a lakosság személyi jövedelemadó befizetései dinamikus növekedést mutattak, a személyi jövedelemadó államháztartási bevételeiben - a 90-es évektöl - képviselt aránya meghaladta a 10 százalékot;

- a kiemelt adónemeken belül megkezdődött az arányeltolódás a fogyasztási jellegü adók felé;

- a költségvetési centralizáció mértéke - az eredeti elképzelések ellenére sem csökkent, így a költségvetés alapvetően meghatározta a GDP több mint felének a felhasználását, valamint szerepe megmaradt a jövedelmek újraelosztásában.

$A$ bevezetett adórendszer azonban rendelkezett néhány olyan sajátossággal, amelynek korrekciója szinte azonnal szükségesé vált.

- A személyi jövedelemadóban a sok adósáv alkalmazása fölöslegesen különböztette meg egymástól ilyen aprólékosan az egyes lakossági csoportokat, a felső 60 százalék pedig túlzott progressziónak bizonyult.

- Az adóbehajtás, ellenőrzés már akkor is csak a mintegy négymillió szja-bevallás feldolgozására és a legnagyobb jövedelmet bevalló vállalkozásokra szükült.

- Ebből adódóan ellenőrizhetetlenné váltak a jelentett költségelszámolások (ebből alakult ki egy sajátos adózáshoz köthető ige, az elköltségelés), illetve a bevételek ellenőrzése is a vállalatok kötelezően elrendelt adatszolgáltatására redukálódott.

Az adórendszer bevezetése tehát egyértelműen a lakosság pozíciójának romlását hozta magával, amely a vállalatok abszolút terhelésének mérséklődésével, valamint a költségvetés bevételeinek korábban elképzelhetetlen mértékü emelkedésével járt. A személyi jövedelemadóból befolyt jövedelmek nagysága arra késztette a kormányt, hogy az önkormányzatnak ígért 100 százalékos részesedést egy év alatt előbb 50 százalékra csökkentse, mely döntésével igen nehéz helyzetbe sodorta az akkor formálódó helyi önkormányzatokat és az egész önkormányzati rendszert. Az önkormányzatok helyzetét elemezve Gulácsi Gábor arra a következtetésre jutott, hogy másodlagos hatásként a személyi jövedelemadó önkormányzatoknak való visszautalása területi alapon csak tovább fokozta a szegényebb, kevés iparral vagy gyorsan felbomló iparral és mezőgazdasági termelési struktúrával rendelkező térségek lemaradását. [4]

A jövedelemadó elöbb ismertetett szerkezete azonban további egyenlötlenségeket épített be a rendszerbe.

- Nem valósult meg a jövedelemarányos közteherviselés, hiszen forrás szerint más és más adó vonatkozott az összevonás alá eső és az összevonás alá nem eső jövedelmekre.

- A bérbruttósítás az adózás előtti és az adózás utáni jövedelmi helyzetet nem módosította, a költségvetési egyenes a valóságban nem tolódott el az eredeti közömbösségi görbéhez képest. Viszont egy évvel később csökkent a legmagasabb 
kulcs, vagyis a legmagasabb kategória megtarthatta a bérbruttósítás egy részét, előnyhöz jutva a többiekhez képest.

A személyi jövedelemadó rendszer ennek ellenére a Németh-kormány gazdaságpolitikájának egyik sikertörténete, hiszen megteremtette az európai alkalmazkodás egyik alapvető feltételét, a munkaerő árának a valós piaci viszonyokon történő számításának lehetőségét, és egyben visszaállította az állampolgárok közteherviselésben való részvételének kötelezettségét. Más oldalról pedig stabil alapra helyezte a költségvetési bevételek egy jelentős részét.

A tanulmány további részében az eddig ismertetett kiinduló állapotból már csak a személyi jövedelemadózás változását elemzem.

\subsection{Változások 1989-1994}

A következő hat év változtatásai 1994-ig a személyi jövedelemadóban a következő lépéseket ölelték fel:

\section{Táblázat. Adóváltozások 1989-1994 között}

\begin{tabular}{|l|l|}
\hline Adókulcsok & $0-56 \%$ \\
\hline Adótábla & 11 sáv helyett 6 \\
\hline Adómentes határ & fokozatosan emelkedik, 1994-töl 110.000 forint \\
\hline Kedvezmény & $\begin{array}{l}\text { alkalmazotti kedvezmény, } \\
\text { gyermekkedvezmény, } \\
\text { a munkahelyi étkezési hozzájárulás } \\
\text { adómentessége. } \\
\text { szellemi munka adókedvezménye }\end{array}$ \\
\hline Ingó-ingatlan & összevonás alá eső jövedelem \\
\hline Külön adózó jövedelem & 20 százalék \\
\hline Munkaadói járulék & csökkentette az adó alapját \\
\hline Befektetések & 20 százalék \\
\hline Forrás: NAV archív & \\
\hline
\end{tabular}

A rendszerváltásig hátralévő két év, majd az utána következő négy év csak adópolitikai értelemben nem hozott jelentősebb változásokat, csupán kisebb kiigazításokat. 1994-re azonban a korábban elképzelhetetlen méretű gazdasági átalakulás, a tulajdonviszonyok alapvető átstruktúrálódása, a teljes termelési vertikum átszerveződése és persze a hagyományos piacok elvesztése okozta transzformációs válság együttes hatásaként kezelhetetlen méretűvé vált az államháztartás hiánya, amelyben különösen nagy részarányt képviselt az államadósság.

Ha a potenciális adófizetők számának alakulása szemszögéből vizsgáljuk az átalakulást, akkor még árnyaltabb a kép. 1989-1995 között az átalakulási törvény, a társasági törvény, a szövetkezeti törvény átalakításával, illetve elfogadásával, a vállalatalapítás és vállalkozásindítás alanyi joggá való tételével megszünt a piacra lépési akadály a 
magánvállalkozásokkal szemben. Viszont korábban elképzelhetetlen megszünési hullám söpört végig a gazdaságon. E két hatás eredőjeként a korábbi alkalmazotti létszám 4,8 millióról 3,7 millióra mérséklődött, miközben a vállalkozó szervezetek száma 400 ezerről csaknem 1 millióra növekedett. Vagyis eltűnt, segélyezetté vált a korábban keresők 25 százaléka, miközben 2,5 szeresére növekedett a vállalkozások száma. Már ekkor nyilvánvaló volt, hogy a vállalkozói létszám növekedése a kényszervállalkozás számának emelkedéséből ered, a munkanélküliség ellen védekezve vették fel egy vállalkozás jogi kötelezettségeit, de kérdéses volt, hogy bármilyen kötelezettségüknek eleget tudnak-e tenni.

A személyi jövedelemadó törvény inkább csak követte a változásokat, megpróbálta például a sávhatárok emelésével ellensúlyozni a harminc százalékot is meghaladó inflációt, ám nem tudta megakadályozni az inflációból adódó terhelésnövekedést.

Mint látható, mindhárom adónemben ebben az időszakban kialakultak a mai helyzet sajátosságai. Eszerint a vizsgált időszakban:

- nemzetközi összehasonlítás szerint a magyar adófizetők nem fizettek lényegesen többet, mint Nyugat-Európában:

- megmaradt a jövedelmek felosztása, csak éppen növekedésnek indultak a külön adózó jövedelmek, és nem, vagy alig viseltek adóterhet:

- az egyéni vállalkozók jövedelmének csökkentése semmiképpen sem volt magyarázható a gazdaságon átsöprő 1992-es, majd a csődtörvény változása miatt bekövetkező 1993-as megszűnési hullámmal. Legális kiskapu teremtődött a feltünően alacsony jövedelmek bevallására és az adóalap mérséklésére elsősorban az ellenőrzés alacsony színvonala miatt: [5]

- ennek egyenes következményeként az adót eltitkolni nem képes, ezért a terheket nagyobb részt viselő alkalmazotti, illetve az adóváltozásokhoz rendkívül rugalmasan alkalmazkodó egyéni vállalkozói rétegre oszlanak személyi jövedelemadó szempontból az adófizetők, ők képezik a legnagyobb létszámú csoportot, viselkedésük alapvetően meghatározza az adóbevételeket.

\subsection{Második szakasz: a Bokros-csomag hatása az adórendszerre}

Egy adópolitika változását nem elsősorban az adósávok emelése vagy mérséklése, az adókulcs változása, vagy akár a kedvezmények átstrukturálódása határozza meg. A változások rangsorolása aszerint lehetséges, hogy mennyiben változik a James Buchanan által adóalkotmánynak nevezett jogszabályi környezet, az adóalkotmány mennyiben garantálja a korábbi kedvezményeket, akár mérsékeltebb formában, vagy éppen más csoportoknak adva azt, vagy éppen ellenkezöleg, milyen szerzett jogokat vesz vissza, vagy ad meg. [6] Ebből a szempontból is alapvető jelentőségű a kormány 1995. március 12-én kihirdetett, Bokros Lajos nevével fémjelzett programja, amelynek csak és kizárólag adópolitikai, ezen belül a személyi jövedelemadózás vetületét és az ehhez kapcsolódó bevételi adatait tekintjük át, hiszen a program értékelése nem ennek a tanulmánynak a feladata. $A$ keresletszükítés, illetve állami kiadás mérséklése és bevételnövelés gazdaságpolitikai célját a következő, a változásokban egyébként alárendelt szerepet játszó adótörvény módosításaival kívánták elérni. 


\begin{tabular}{|l|l|}
\hline Adókulcsok & $20-48 \%$, majd 20-42 \% \\
\hline Adótábla & 11 sáv helyett 6 \\
\hline Adómentes határ & Megszünt \\
\hline Ingó-ingatlan & Összevonás alá eső jövedelem \\
\hline Külön adózó jövedelem & $20 \%$, az ingó és ingatlan értékesítése ide került \\
\hline Kedvezmények & $\begin{array}{l}\text { Tözsdei befektetések összegére adott } \\
\text { úgynevezett adóhitel, kezdetben korlátozás } \\
\text { nélkül. }\end{array}$ \\
\hline Munkavállalói járulék & $\begin{array}{l}\text { Nem csökkentette az adó alapját. } \\
\text { Növelték a társadalombiztosítási hozzájárulás } \\
\text { alá eső jövedelmek csoportját, ide tartoztak már } \\
\text { szerzői jogvédelem alá eső tevékenységek is. }\end{array}$ \\
\hline Tőkejövedelmek & $\begin{array}{l}\text { Állampapír-befektetések utáni hozamok adója 0 } \\
\text { százalék, a tőzsdei árfolyamnyereség adója 10 } \\
\text { százalékra mérséklödött }\end{array}$ \\
\hline
\end{tabular}

Forrás: NAV archív

\subsection{A Bokros-csomag várt és nem várt hatásai}

Bár a Bokros-csomag jelentős részét az Alkotmánybíróság döntésével hatályon kívül helyezte - a baleseti járulék kivételével nem változtatott az adótörvények módosításán, hiszen az nem érintette az alkotmányos jogokat. [7] A magyar alkotmányban az adófizetés mint a közterhekhez való hozzájárulás egyoldalú, viszontszolgáltatás nélküli állampolgári kötelezettség szerepel, ennek szellemét nem sértette a Bokros-csomag. A megszorító intézkedések a kényszerü szünet után két éven keresztül léptek hatályba, és eredményként könyvelte el az akkori kormány, hogy a fizetési mérleg hiányát nemzetközi összehasonlításban is gyorsan és nagy arányban sikerült mérsékelni. Ez önmagában visszaállította a nemzetközi pénzpiacok bizalmát és finanszírozhatóvá vált a megmaradó és rövidesen változatlan formában újratermelődő hiány. A négyéves politikai ciklus második felében némi visszarendeződés volt megfigyelhető, elsősorban a kedvezmények, az adójóváírás, illetve a sávhatárok módosításában, de ez alapvetően nem változtatta meg az adórendszer jellegét.

Ha a felsorolt változásokat elemezzük, akkor nyilvánvaló, hogy elsősorban a nyugdíjas, az alkalmazotti, valamint a gyermekes családok kerültek rosszabb helyzetbe. Ha nem szociálpolitikai szempontból vizsgáljuk a kérdést, hanem a mintegy 400 ezer egyéni vállalkozó és csaknem egymillió összes vállalkozás szempontjából, akkor a következő különbségek adódnak a kétféle adórendszer között:

A társadalombiztosítási járulék levonhatóságának eltörlése növekvő költséget eredményez mind az egyéni, mind a társas vállalkozások szintjén.

A 0 kulcsos jövedelmi sáv megszúnése az egyéni vállalkozókat, illetve a társas vállalkozások tulajdonos-vezetőit, (bt.beltag-ügyvezető igazgató) kizárta a mentes körből, hiszen az adójóváírás csak alkalmazotti státuszhoz járt. Vagyis ez a csoport nem kapott mentességet még akkor sem, ha a minimálbért kereste meg.

A szerzői jogvédelem alá eső tevékenységek korábbi 100000 forintos adóalapcsökkentő kedvezménye 50 ezer forintos adókedvezménnyé változott, amely mindenképpen 
mérsékelte jövedelemhatártól függően a kedvezmény reálértékét. A szerzői jogi védelem alá eső tevékenységek körének mérséklése, ezen jövedelmek járulékfizetés alá vonása mintegy 170 ezer adózót hozott hátrányosabb helyzetbe.

Erőteljes preferencia figyelhető meg a vagyonfelhalmozáshoz kötődően, illetve a pénzügyi egyensúlyhoz, a beruházások növeléséhez füződő általános érdek miatt a betéti, állam papírbefektetések utáni hozamok adóztatásában ( 0 kulcs $)$, illetve a tőzsdei árfolyamnyereség 10 százalékra való mérséklésével 1995-ben és 1996-ban.

A Bokros-csomag intézkedéseivel egy, az 1988-as adóreformtól gyökeresen különböző személyi jövedelemadó rendszer lépett életbe, amely a méltányosság és igazságosság addig preferált szempontjai helyett a hatékonyságot helyezte elötérbe, nem utolsósorban a fokozódó ellenőrzések révén is. Ez az adórendszer minden további változtatás nélkül is erőteljesebben képes lehetett az inflációs adóforintokból származó adóbevétel növelésére, hiszen bevezetését a vártnál magasabb, mintegy 12 százalékos áremelkedés kísérte, amely automatikusan emelte a befizetéseket nemcsak nominál, hanem reálértéken is, miközben befagyasztotta az adókedvezményeket. (Az adócsökkentő tételek ugyanis nem követik a progressziót, egészen más hatással jár az éves jövedelemböl levonni korlátozás nélkül fölülröl, a határadókulccsal adózó rész valamekkora százalékát, amely együtt növekszik az inflációval, mint a fizetendő adóból levonni egy fölülről korlátos, maximált összeget.)

Mindezek hatására másfajta személyi jövedelem adórendszer jött létre, amely gyakorlatilag figyelmen kívül hagyta a szociális szempontokat, a szociálpolitikára hagyva a méltányosság és igazságosság eleinek érvényesítését, erőteljesen differenciált a jövedelmek között azok forrása szerint, kifejezetten preferálta a tőkejövedelmeket, miközben összekötötte a jövedelemadót a társadalombiztosítási elvonásokkal a béreken túlmenően is. Ezt a jelleget még csak erősítette nemcsak az említett járulékalap-szélesítés, hanem az a szabály is, amely heti 36 óra alatti munkaviszony esetében az összes többi jogviszonynál kötelezővé tette a teljes társadalombiztosítási járulék megfizetését, vagyis akadtak duplán fizető részállású vállalkozók. Vagyis az adó - és járulékkötelezettség szorosan összekapcsolódott egymással.

\subsection{Harmadik szakasz: adórendszer-változások 1998-2002}

A kormányváltást kísérő gazdaságpolitikai lépésváltás a monetáris és fiskális restrikció, az egyensúlyteremtés helyett a növekedéspárti gazdaságpolitikát helyezte előtérbe, és határozott koncepcióval rendelkezett arról, pontosan mely csoportok számára kívánja erősíteni a horizontális és méltányossági szempontokat és hol kívánja az adózás közvetett érdekeltségével megteremteni a társadalmilag hasznosnak ítélt családmodell megvalósulását.

\section{Táblázat. Adóváltozások 1998-2002 között}

\begin{tabular}{|l|l|}
\hline Adókulcsok & $20-40$ százalék \\
\hline Adótábla & 3 sáv \\
\hline Külön adózó jövedelem & változatlan, 20 százalék \\
\hline Kedvezmények & $\begin{array}{l}\text { Gyermekkedvezmény, lakásvásárlók } \\
\text { hiteltörlesztésének kedvezménye, }(\end{array}$ \\
\hline
\end{tabular}




\begin{tabular}{|l|l|}
\hline & $\begin{array}{l}\text { törlesztőrészlet 40\%-a, maximum évi } 240 \text { ezer } \\
\text { forint erejéig), tandijkedvezmény. } \\
\text { De a természetbeni juttatások utáni } 44 \\
\text { százalékos adó mellett } 11 \text { százalékos } \\
\text { egészségügyi hozzájárulást is kellett 2000-től } \\
\text { kezdődően fizetni. }\end{array}$ \\
\hline Munkavállalói járulék & $\begin{array}{l}\text { Ismét csökkentette részlegesen az adó alapját. } \\
\text { A munkaadói járulék } 10 \text { százalékkal } \\
\text { mérséklödött 39-röl } 29 \text { százalékra. }\end{array}$ \\
\hline Tőkejövedelmek & $\begin{array}{l}\text { Az árfolyamnyereség } 20 \text { százalékos adója } \\
\text { kiterjedt a tőkeszámlán nyilvántartott } \\
\text { értékpapírok árfolyamnyereségére is, így } \\
\text { megszünt a tőzsdén jegyzett cégek } \\
\text { részvényeinek adott mentesség. Szélesedett } \\
\text { viszont a veszteségleírás mértéke. }\end{array}$ \\
\hline
\end{tabular}

Forrás: NAV

A családi támogatás 2002-ben érte el csúcspontját, miközben adójóváirásra 71 milliárd forint jutott, 76 milliárd forintnyi adóbevétel-kieséssel támogatta a kormány a gyermekeket nevelő családokat.

Az adótábla egyszerüsítése, a kedvezmények lakossági csoportokon belüli átpozícionálása ellenére sem nagyarányú változásról, sem reformról nem beszélhetünk. Viszont 1998-tól kezdve radikálisan, 10 százalékponttal mérsékelték a munkáltatók által fizetett társadalombiztosítási járulékot. A korábbi 39 százalékról 29 százalékra csökkent az elvonás mértéke, mondván, a magas járulék miatt nem képződnek új munkahelyek. A 10 százalékos mérséklést csak részben ellensúlyozta a növekvő eho, átlagosan 1,06-1,91 százalékkal emelve az egészségbiztosítási járulék effektív kulcsát. [8]

A minimálbér 25 ezer forintról 40 ezerre emelkedett, amely elsősorban a vállalkozókat érintette hátrányosan. Érdekes módon az emelést nem kísérte a szakirodalomban elfogadott összefüggés, a munkanélküliség emelkedése, sőt az általános konjunktúra viszonyai között mérséklődött munkanélküliségi ráta. [9] A minimálbér emelése egyben a járulékalap növelését is jelentette, a társadalombiztosítási járulékból befolyt összeg végül nem mérséklődött, mert az alacsonyabb munkaadói elvonás és ezzel párhuzamos minimálbér-emelés együttes hatása az emelkedés maradt. Az Orbán-kormány tehát alapvetően átrendezte a kedvezményeket, amelyek összességében nem változtak, nem a szociálisan legrászorultabbak támogatását vállalta fel, hanem a keresőképes, középosztálybeli nagycsaládosokra helyezte a hangsúlyt. (Sőt a családi kedvezményeket, családi pótlékot csak iskolalátogatási igazolással rendelkező gyerekek után lehetett felvenni.) Viszont erőteljesen élt a járulékcsökkentés eszközével, de nem bolygatta meg a járulékokból finanszírozott juttatásokat.

Az adott négy év alatt feltűnően növekedtek, átlagosan 155,7 milliárd forinttal, mintegy 24 százalékkal a személyijövedelemadó-bevételek, emelkedtek - igaz, mérsékelt ütemben - a társadalombiztosítási hozzájárulásból származó összegek, lényegesebb változást azonban nem tükröznek sem az áfa, sem a társaságiadó-bevételek. Ugyanakkor jelentősen megnövekedett az adót fizető - nemcsak bevalló - egyéni vállalkozók száma, és az emelkedést részben magyarázhatja a nagyarányú adókedvezmények hatása is. 
Szintén növekvő tendenciát mutatott az adót fizető alkalmazottak száma is - szintén részhatásként betudható a csökkenő munkanélküliségi ráta miatt elhelyezkedők száma, illetve a már említett minimálbér-emelés 2001-ben, amit nem követett az adójóváíás-emelkedés, ezért a legalacsonyabb sávba eső jövedelmeket is terhelte adófizetési kötelezettség. $A z$ effektív személyijövedelemadó-kulcs ebben az időszakban volt a legmagasabb, ugyanakkor a bevételek növekedése jóval meghaladta a korábbi évekét, ami arra utal, megváltozott az adófizetök magatartása, önként visszaléptek az adózói - legális - körbe.

A következő négy év során hasonló mértékü, de ellenkező előjelü változások mentek végbe, holott az adóterhelés mérséklődött mindhárom adónemben, igaz eltérő években.

\subsection{Negyedik szakasz: adórendszer-változások 2002-2010}

A kormányváltás után úgynevezett száz nap programja a választás során tett - részben adópolitikai lépések - beváltását hozta magával, míg Medgyessy Péter távozása után újabb megszorító csomag következett.

5.Táblázat. Adóváltozások 2002-2010 között

\begin{tabular}{|c|c|}
\hline Adókulcsok & $\begin{array}{l}2002-2006: 18-38 \% \\
2004-201018-36 \%\end{array}$ \\
\hline Adótábla & $\begin{array}{l}\text { háromkulcsos 2004-ig, utána két kulcsos } \\
\text { 2006- magánszemélyeket is terhelő } 4 \\
\text { százalékos különadó }\end{array}$ \\
\hline Külön adózó jövedelem & 20 százalék \\
\hline Kedvezmények & $\begin{array}{l}2002-2006 \text { között mérséklődött, majd 2006-tól } \\
\text { teljesen megszünt a gyermekkedvezmény, } \\
\text { lakásvásárlók hiteltörlesztésének kedvezménye, } \\
\text { a Sulinet számítástechnikai cikkek vásárlásához } \\
\text { adott adókedvezmény, a felnőttképzési } \\
\text { kedvezmény. helyette a minmálbért mentesítette } \\
\text { a teljeskörű adójóváírás. } \\
\text { De a természetbeni juttatások utáni } 44 \\
\text { százalékos adó mellett } 11 \text { százalékos } \\
\text { egészségügyi hozzájárulást is kellett } 2000 \text {-től } \\
\text { kezdődően fizetni. }\end{array}$ \\
\hline Munkavállalói járulék & $\begin{array}{l}\text { Ismét nem csökkentette részlegesen az adó } \\
\text { alapját. A munkaadói járulék } 10 \text { százalékkal } \\
\text { mérséklődött.(39-ről } 29 \text { százalékra.) } \\
\text { Évi } 6748850 \text { forint bruttó kereset fölötti kereset } \\
\text { után úgynevezett szolidarítási járulékot kellett } \\
\text { fizetni. }\end{array}$ \\
\hline Tökejövedelmek & $\begin{array}{l}\text { Adómentessé váltak a tőzsdei befektetések } \\
\text { hozamai }\end{array}$ \\
\hline
\end{tabular}

Forrás: NAV archív 


\subsection{0-Egykulcsos adórendszerre való átállás}

A számok alapján már 2010-ben egyértelművé vált, hogy a korábbi keretek között nem maradhat a magyar személyi jövedelemadózás, sem az adófizetők számában, sem az általuk fizetett egyre nagyobb adóterhelés révén beszedett adók nem érték el az államháztartás finanszírozásához szükséges minimumot, ahogy az ösztönző szerep, avagy a szociális érzékenység sem volt jellemző.

Bár a korábbi években elsősorban a szlovák, egykulcsos, 19 százalékos kulcsot alkalmazó rendszert mintaként véve többször felbukkant a lineáris adórendszer bevezetésének gondolata, ez a hivatalos adópolitika szintjén 2010. nyarán az úgynevezett első gazdasági akcióterv során öltött testet, méghozzá úgy, hogy a kormány azt ígérte, két év alatt bevezetik az egykulcsos, családi elemekkel könnyített jövedelemadót és az adójóváírás megszűnik. [10] Ennek megfelelően alapvetően átszabták a személyi jövedelemadó rendszert, a 2011-esztendő alapvető változást hozott a két kulccsal és adóvisszatérítéssel is meglehetősen bonyolult, a minimálbért, vagy annak egy részét tehermentesító progresszív adótáblát magáénak tudható szja rendszerben is. Megszűnt a két kulcs, helyette előbb 16, majd 15 százalékos egykulcsos, úgynevezett flat rate kapott szerepet.

\section{Táblázat. Adóváltozások 2010-2018 között}

\begin{tabular}{|l|l|}
\hline Adókulcs & egy kulcs 16, majd 15 százalék \\
\hline Külön adózó jövedelem & egy kulcs, 16, majd 15 százalék \\
\hline Kedvezmények & $\begin{array}{l}\text { Családi kedvezmény, családi járulék } \\
\text { kedvezmény, első házasok kedvezményre, } \\
\text { fogyatékkal élők kedvezménye } \\
\text { Cafeteria egyre szükülnek a kedvezményes } \\
\text { csoportok, a, terhelése közelít a munkabéréhez }\end{array}$ \\
\hline Munkavállalói járulék & $\begin{array}{l}\text { Átalakul szociális hozzájárulási adóvá, mértéke } \\
17,5 \text { százalék. } \\
\text { Munkavállaló járulék 17+1,5 százalék.é }\end{array}$ \\
\hline Tőkejövedelmek & $\begin{array}{l}\text { Tartós befektetési számlán tartott befektetések } \\
\text { esetén 3 évi lekötés után 10 százalék, } 5 \text { év után } \\
\text { teljes adómentesség vonatkozik. }\end{array}$ \\
\hline
\end{tabular}

Forrás: NAV archív

Szintén megszünt a korábbi rendkívül széttagolt és elsősorban fogyasztást preferáló kedvezményrendszer, helyét az elsősorban két, vagy többgyerekeseket preferáló családi adókedvezmény, majd 2014-től az ezt kiegészítő, a legszegényebbeket is a kedvezményes körbe bevonó családi járulékkedvezmény kapott szerepet. Emellett az első házasok, a fogyatékkal élők kaptak-kapnak kedvezményt, gyakorlatilag megszünt a biztosítások adókedvezménye, ahogy az informatikai fogyasztást sem preferálja a továbbiakban az adópolitika. Jelentősen megemelkedett a minimálbér és miután megszünt annak adómentessége, jelentősen növekedett a tényleges adófizetők száma, az egy före jutó 
adóbevétel és természetesen a költségvetés is növekvő bevételekre számíthat a lakosságtól. Eközben azonban alapvető fordulat ment végbe a munkaerőpiacon, a korábbi 10 százalék fölötti munkanélküliségi ráta 4 százalék alá mérséklödött, amely tovább növelte az adófizetök számát, az egy före jutó adó nagyságát is, amely még most sem érte el nominál értékben ismét a 2004-es szintet.

\section{Következtetések}

Mint látható, rendkívül nagyléptékü változások mentek végbe a politikai ciklusokhoz igazodva átlagosan négyévente, de az egyes adóváltozások hatását leginkább az állampolgárok reakciójával érdemes mérni. Erre pedig megfelelő mutató az adót fizetők számának alakulása, hiszen az adó fizetése, vagy nem fizetése, avagy mindenáron való elkerülése akkor jellemzi az adófizetők magatartását, ha nem érzik egyenrangúnak a cserét, a közjavakért fizetett ár túlságosan sok a kapott „szolgáltatásért” cserébe.

Az alábbi táblázat pedig azt is mutatja, hogy nem feltétlenül az egy före jutó, effektív adó nagysága határozza meg az adófizetői magatartást.

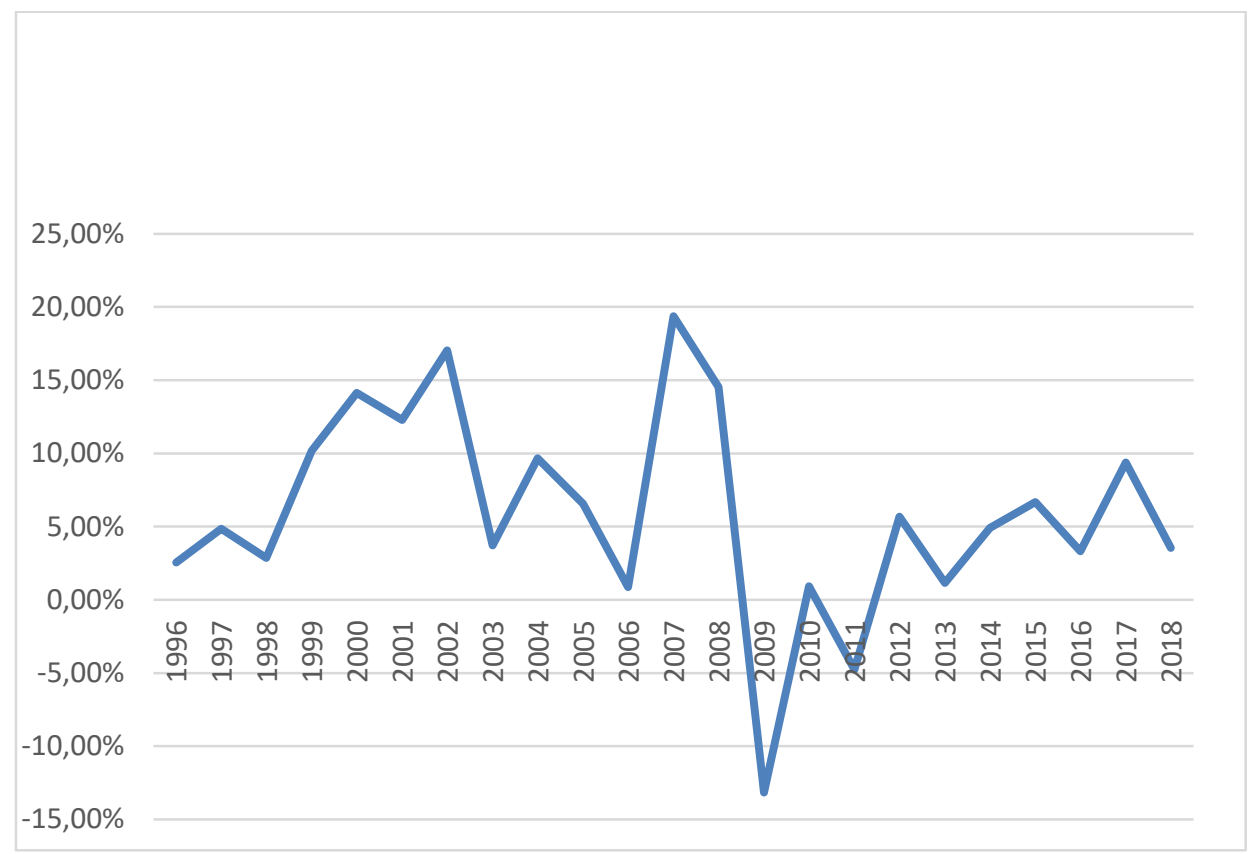

1. ábra. Az SZJA bevételek folyóáron számolt növekedése 1995-2018

Az adófizetők számának alakulása nem teljes, tekintettel arra, hogy az éves adóbevallások adatai már nem állnak rendelkezésre. Ugyanakkor az Európai Unióhoz való csatlakozásra való felkészülés jegyében a statisztikai adatszolgáltatás 1995-töl következő az Eurostat adatbázisban. a korábbi kimutatások más módszertan alapján készültek. Ezért az adóbevételek változását, amely a lakossági befizetések éves, folyó áron számolt változását mutatva, így tükrözve a végbement váltoások s ar erre adott lakossági „válaszok” együttes hatását. 
5.Táblázat.Adófizetők számának és az egy före adó alakulása 2002-2015

\begin{tabular}{|l|l|l|l|l|l|l|l|l|l|l|}
\hline Év & 2002 & 2003 & 2004 & 2005 & 2006 & 2011 & 2012 & 2013 & 2014 & 2015 \\
\hline $\begin{array}{l}\text { Adófizetők } \\
\text { száma }\end{array}$ & $\begin{array}{l}3860 \\
279\end{array}$ & $\begin{array}{l}3220 \\
438\end{array}$ & $\begin{array}{l}3079 \\
517\end{array}$ & $\begin{array}{l}3025 \\
639\end{array}$ & $\begin{array}{l}3452 \\
148\end{array}$ & $\begin{array}{l}3343 \\
260\end{array}$ & $\begin{array}{l}4000 \\
162\end{array}$ & $\begin{array}{l}4009 \\
937\end{array}$ & $\begin{array}{l}4111 \\
444\end{array}$ & $\begin{array}{l}4165 \\
995\end{array}$ \\
\hline $\begin{array}{l}\text { Egy före } \\
\text { jutó adó }\end{array}$ & 304 & 372 & 400 & 441 & 431 & 323 & 339 & 329 & 349 & 373 \\
\hline
\end{tabular}

Forrás: NAV archív

Az optimális adópolitika mindig egy kompromisszum eredménye, amelyben az adófizetök elfogadják, hogy fizetniük kell, de a közjavakért fizetett adóár nem haladja meg a méltányos és igazságos kereteket. A progresszív adótábla nem biztos, hogy maradéktalanul megvalósítja a fizetőképesség elvét, hiszen a beszedett adó nagymértékben függ egy-egy adózási csoport fizetési hajlandóságától. Vagyis a választott adórendszert tulajdonképpen a végeredmény minősíti.

A rendszerváltás utáni periódusokat az újból és újból megbomló pénzügyi egyensúly és az ezzel összefüggő hangsúlyváltások határolják el egymástól, olykor egy-egy politikai cikluson belül is. Az adópolitika ebben alárendelt szerepet kapott, és hol a vertikális, hol a horizontális méltányosság erőteljesebb érvényesítése került előtérbe, de csak korlátozottan. A legtöbbször inkább a mind súlyosabb hiány miatti egyre szükülő keretek között az adóbevételek növelése és ezzel egyidejüleg, ellentétes törekvésként a külföldi befektetők számára elönyös környezet garantálása jelentette a föbb célkitüzéseket. Az egyensúlyi szempontok 1994 utáni megerősödése nem tette lehetővé az adórendszer nagyobb léptékű reformját, a kisebb-nagyobb kiigazítások rövid távon garantálták a bevételi tervek teljesülését, de a döntések hatóköre a politikai vetésforgó miatt eröteljesen leszükült, a döntések fókuszában mindig a következő évi adóbevétel, és nem a négy év múlva képződő adóalap állt.

$A z$ adóreform után eltelt első hét esztendőben a rendszer - beleértve mindhárom föbb adónemet - megtartotta eredeti, a szociálpolitika bizonyos elemeit tükröző sajátosságait, alacsonyabb adóterhet rakva az alacsonyabb keresetű rétegekre mind a személyi jövedelemadózásban, mind a forgalmi adózásban.

Ezek a sajátosságok az 1995-ös kiigazítás után fokozatosan eltüntek, a személyi jövedelem-adórendszerből, majd az ÁFA rendszerböl kikerültek a szociálpolitika érvényesülését segítő kedvezmények, engedmények. Az adóterhelés fokozatosan az átlagkeresetűekre rakódott. Az egyre növekvő költségvetési hiány, majd a 2008-as pénzügyi válság maga alá temette a korábbi személyi jövedelemadó rendszert is, csökkenő adófizetői szám és növekvő átlagos adóteher jellemezte a rendszert 2010-ig.

Ezután részben az adóár csökkenése miatt, másrészt az állami szolgáltatásokért fizetett egykulcsos, a korábbi évektől eltéröen alacsony adókulcs és csökkenő társadalombiztosítási terhek, valamint az átlagbér összegét jóval meghaladó mértékü, család - gyerek támogatások révén ismét kevesebben kerülik el az adót, hiszen legálisan is mérsékelhetik annak nagyságát.

Az egykulcsos adórendszer bevezetése nem ígért egyértelmü fordulatot, de ha az adófizetők számának alakulását és az egy adófizetőre jutó terhek számait nézzük, mindenképpen beváltotta az igazából hozzá nem füzött reményeket. 


\section{Irodalomjegyzék}

[1] „Adózás 1988-1996” Dr Ékes Ildikó. Statisztikai Szemle 1993/1-2

[2] „1987. évi VI. Törvény a személyi jövedelemadóról,” Magyar Közlöny, 1986.

[3] „Az adók és a föbb makrogazdasági mutatók viszonya,1988-1996”, Pénzügyminisztérium, belső anyag

[4] "A személyi jövedelmek helyi adóztatása, illetve a személyi jövedelemadó, mint a helyi önkormányzatok bevétele," Gulácsi Gábor,Szociálpolitikai Értesítő 1993/1-2. szám 436. oldal

[5] „A 90-es évek magyar gazdaságpolitikája”. Antal László: in: Fejezetek a gazdaságpolitikából szerk Veress József, Aula,2004

[6] „Adózási alkotmány Leviatan számára”. Geoffrey Brennan - James Buchanan, in: Szociálpolitikai Értesítő, 1993/1-2 szám

[7] „Határozat jogszabály alkotmányellenességének utólagos vizsgálatára irányuló indítványok, valamint mulasztásban megnyilvánuló alkotmányellenesség megszüntetésére indított hivatalból indított eljárás alapján”. Complex CD Jogtár (2006):

[8] „Az Egészségbiztosítási Alap pénzügyi instabilitásának okairól”. Szigeti Szabolcs, IME 2007/2

[9] „Mikroökönomia középfokon, "H.R.Varian, Közgazdasági és Jogi Könyvkiadó 2005

[10] „Az egykulcsos személyi jövedelemadó hatásai”. MSZOSZ 2012.vitaanyag 